\title{
COVID-19 and Fake News
}

\author{
Javier Bustos Díaz ${ }^{1,2}$ and Ruben Nicolas-Sans $1,2, * \mathbb{D}$
}

1 ESIC Business and Marketing School, Passeig Santa Eulália, 2, 08017 Barcelona, Spain; javier.bustos@esic.edu 2 Research Department, ESIC University, Avenida Juan XXIII, Pozuelo de Alarcón, 12, 28224 Madrid, Spain

* Correspondence: ruben.nicolas@esic.edu

check for

updates

Citation: Bustos Díaz, J.;

Nicolas-Sans, R. COVID-19 and Fake

News. Encyclopedia 2021, 1, 1175-1181.

https://doi.org/10.3390/

encyclopedia1040088

Academic Editor: Stephen Bustin

Received: 23 September 2021

Accepted: 2 November 2021

Published: 5 November 2021

Publisher's Note: MDPI stays neutral with regard to jurisdictional claims in published maps and institutional affiliations.

Copyright: (C) 2021 by the authors. Licensee MDPI, Basel, Switzerland. This article is an open access article distributed under the terms and conditions of the Creative Commons Attribution (CC BY) license (https:/ / creativecommons.org/licenses/by/ $4.0 /)$.
Definition: COVID-19 can be defined as a global pandemic caused by a coronavirus that first surfaced in 2019. Fake news refers to false reports that can be found in digital media. The combination of these two concepts creates an especially mismanaged situation that can result in widespread unease among the population, to whom the news appears continuously and without quality filters.

Keywords: COVID-19; fake news; media literacy

\section{Introduction}

We live in a digital society. To put this fact into context, we must focus on the data; $48.97 \%$ of the world population uses the Internet, according to the World Bank [1]. This percentage grows exponentially if we look only at the ratio of developed countries with advanced technological infrastructures and notable levels of industrialisation, where this percentage is more than $77.42 \%$ according to the same source. The Internet has changed the way in which the world is seen and understood, but, above all, it has changed the way in which people communicate. Human relationships could not be understood today without social media, which has a penetration rate of 70\% in Europe and North America [2]. In fact, according to data provided by Statista [2], in a single minute on the Internet, 69 million messages are sent from WhatsApp and Facebook Messenger, there are 5000 downloads on TikTok, $500 \mathrm{~h}$ of videos are uploaded onto YouTube, 197.6 million emails are sent, and there are 2 million Twitch views. In summary, society as a whole spends a large part of its time on the Internet both for leisure and for work; mankind today lives in a network society [3].

However, although leisure and connectivity are an essential part of people's daily lives, information gathering is an activity that is also carried out through these channels. The data provided by Digital News Report [4] on this question establishes that $82 \%$ of people use digital media (including social networks) as an information channel. The smartphone is the preferred device for accessing news, with $69 \%$ compared to the $49 \%$ who prefer the computer, and $18 \%$ who prefer the tablet. However, all social progress brings with it a series of consequences. In this case, although society is more interconnected than ever, it also has to face a hyperproduction of pseudo-contents [5] (contents containing intentionally false information) for which perhaps it is not prepared, and which have become a globalised problem that generated great confusion during the pandemic caused by COVID-19.

\section{What Is Fake News? Towards a Definition}

The Oxford Dictionary, which selected this combination of words as the word of the year in 2017 [6], defines fake news as "false reports of events, written and read on websites". Whilst it is true that this explanation can show with total clarity what fake news is, some authors go a step further and try to argue and qualify these words. In this sense, Gelfert argues that, although we understand disinformation as a type of information, fake news must be classified as a type of news. At the same time, he explains that its two most obvious characteristics are based on the type categorised as news, since fake news is presented as news, but unlike journalistic or academic information, it aims to deceive the target audience [7]. 
Intentionality is one of the key elements when it comes to differentiating fake news from another series of casuistry that may occur [8,9]. Within this idea it is explained that fake news should not be confused with other types of erroneous or misleading information, namely, errors by journalists or politicians, rumours or conspiracies without association to specific news articles, and entertainment-oriented formats such as satire [8].

Therefore, although we can understand fake news as being those false reports on web pages [10], we must also assume that there are, both in online press and on web portals, as well as on other information sites, a whole series of news and facts that, whether due to lack of journalistic rigour or simple human error, cannot be considered fake news.

For its part, the European Commission [11] defines this phenomenon, and explains that disinformation is "verifiably false or misleading information created, presented and disseminated for economic gain or to intentionally deceive the public". the knowledge of the agents involved in it, and the development that is spread without the intention to mislead, and often shared because the user believes it to be true.

The spread of both disinformation and misinformation can have a range of consequences, such as threatening our democracies, polarising debates, and putting the health, security, and environment of EU citizens at risk. This matter has been amplified since the spread of COVID-19 [11]. Large-scale disinformation campaigns are a major challenge for Europe and require a coordinated response from EU countries, EU institutions, social networks, news media, and EU citizens.

The Commission has developed a number of initiatives to tackle disinformation [11]:

1. The Code of Practice on Disinformation lays out a set of worldwide self-regulatory standards for industry.

2. The European Digital Media Observatory is a European hub for fact-checkers, academics, and other relevant stakeholders to support policy-makers.

3. The action plan on disinformation aims to strengthen EU capability and cooperation in the fight against disinformation.

4. The European Democracy Action Plan will develop guidelines for obligations and accountability of online platforms in the fight against disinformation.

5. The Communication on "tackling online disinformation: a European approach" is a collection of tools to tackle the spread of disinformation and ensure the protection of EU values.

6. The COVID-19 monitoring and reporting programme, carried out by signatories of the Code of Practice, acts as a transparency measure to ensure accountability in tackling disinformation.

Within the scope of fake news, there is another series of terms and concepts that are related, and yet it is not possible to find an exact definition of the phenomenon. This is the case of post-truth, which authors such as Capilla have worked on and analysed, and have concluded that, ultimately, it consists of the substitution of facts for beliefs and emotions in social discourses [12].

\section{The History of Fake News}

Although the term fake news is associated with the former President of the United States, Donald Trump $[8,9,13]$, some authors point out that the dissemination of false information with a preconceived and malicious intention has existed for centuries. Regarding this fact, Salas Abad points out some of the historical moments where it can be considered that fake news was generated. In this sense, it can be remembered that Socrates already classified the sophists as transmitters of false news, or in the Middle Ages papal bulls were falsified for their own benefit [14]. On the other hand, we cannot fail to appreciate historical events that the author points out, such as the one that arose with Orson Welles' The War of the Worlds in 1938, which Salas Abad [14] compares with fake news. Following radio broadcasts of Welles' book, a great stir and social impact were generated despite the incidents being fictitious, due to the fact that the narration was so realistic that many citizens believed that an alien invasion was actually occurring. 
Other authors explain that the term fake news itself appeared more than a century ago, specifically in Harper's Weekly in 1925 entitled "Fake News and the Public" [15]. In this sense, works such as the study conducted by Rodríguez-Fernández, in which fake news was collected and analysed with the objective of identifying the types of organisation in Spain most affected by fake news and the nature of the false information spread, conclude that, although the current stage of proliferation that exists within the current communication system has shown social concern for this phenomenon, it is evident that this is not a new event, and it has occurred at many moments in our recent history, especially within the political sphere as an element of electoral propaganda [16].

Finally, as mentioned at the beginning of this section, fake news has become a relevant part of the current communication system [17], which is found in both the referendum on Brexit and the election of Donald Trump in the United States, two moments of its proliferation [7].

\section{Why Has Fake News Been So Successful during the Period of COVID-19?}

As described in the opening paragraphs, society today is hyper-connected. For this reason, there is a rapid dissemination of information. This does not imply that all information is verified, and social networks have allowed for the dissemination of verified and unverified content, prepared by professionals and non-professionals, creating an ideal context for spreading fake news [17].

Consequently, and especially in a period of need for information such as that generated by the COVID-19 pandemic, a problem of spreading fake news with the intention of deceiving the general public has been brought about and, as described, can be found on the Internet's social networks. Its rapid dissemination is what is known as viralisation, which provides the perfect setting for fake news to spread [18].

In this new scenario, information technology and its distribution have relegated traditional media to second place; that is to say, journalism has ceased to be the guarantor of information in favour of the dissemination and speed that a retweet on Twitter or a "like" on Facebook can achieve [19]. This first factor, the decline of journalism in favour of the dissemination of social networks, has been found to be one of the decisive factors when fake news finds a media ecosystem without a gatekeeper that acts as a natural filter of information.

However, this is not the only factor. If there is a lack of journalism capable of assuming control of the flow of communication, media literacy is presented as the most solid alternative when it comes to dealing with fake news. However, the general public on many occasions do not know how to recognise false information when it is presented to them [18].

Another aspect of this new media ecosystem that has become one of the main drivers of fake news is the brevity of the exposure linked to the use of social media networks. On this issue, the new communication technologies are even supplanting those that until now were essential, for example, in the company. Thus, the use of WhatsApp has been normalised and has relegated e-mail in many aspects. In other words, as an attempt to achieve faster results, less is being written [20].

On the other hand, the constant use of social networks is itself a determining factor when it comes to being a victim of fake news. This is because the time of exposure to false news, in the specific case of Facebook, can lead users to consume this type of information because of their constant, albeit accidental, consumption from the exposure [21].

Finally, a determining factor when it comes to understanding why fake news spreads so easily and, above all, acquires the status of news for those who consume it is the viral effect of social networks. That is, legitimacy based on emotional relationships between users and their political bias is acquired once they are shared by "friends" on social networks [22].

In any case, there are studies that conclusively demonstrate that the users of social networks were motivated by various factors to share news related to COVID-19. "It is their 
behaviour, either vigilant or ignorant when consuming and disseminating messages related to COVID-19, that contribute to fake news spreading and its grave impacts on society" [23].

Therefore, according to the conclusions of Pérez-Dasilva et al., it has become clear that, in addition to facing an economic and public health crisis, we are facing an information crisis [13].

Following this same line of argument, the work carried out by Casero Ripollés presents empirical findings that reaffirm this hypothesis and link the situation experienced as a result of COVID-19 with the increase in the search for information. "In the case of COVID$19,92 \%$ of adults in the United States frequently accessed the news about the pandemic, registering an increase of $34 \%$ over the period prior to the health emergency" XXI [24].

Lastly, and in relation to that which was put forth in the article by Gutiérrez et al., titled "Fake news about COVID-19: a comparative analysis of six Ibero-American countries", it is shown that the percentage of fake news that reached the traditional media is almost insignificant, which reinforces the hypothesis that fact-checking journalism is a practice that does indeed help to combat the problem of fake news [25].

\section{Lack of Media Literacy}

Based on the problems raised, media literacy is more necessary than ever. Authors such as Fernández-García have already stated even before the proliferation of fake news that came from the COVID-19 pandemic that, "If new generations obtain their information from social networks and other online resources, they must learn to decode what they read" [26].

However, the problem of the need to promote media literacy is not linked to fake news. Indeed, we could affirm that, if it had been considered a formal element within compulsory education, we would have witnessed a decline in fake news instead of its proliferation. Based on this, it is necessary to "analyse, study and examine the contents and objectives of literacy, to adapt them to a multimodal and media system" [27].

This last idea, raised by Gutiérrez and Tyner, is argued by the authors based on the following premise: if we understand education to be the preparation of the society of tomorrow we cannot leave the environment, which is becoming more and more digital every day, out of the study. In contrast, over the last few decades, this aspect has been relegated to the background [27].

This same premise has been defended and expanded from different angles by various academics who have even proposed direct and applicable solutions in the current context. In this sense, Aguaded et al. argued for the introduction of digital and informational education under the protection of active public policy, with the purpose of creating a media-literate general public through critical, participatory, and creative training. These same authors, among other premises, proposed at the same time the introduction of programs that would allow the general public to learn under a mixture of critical training with interpretative and investigative journalism [5].

All these questions raised so far were collected by Alcolea and Reig:

"It is a challenge to face the power of the media and to accept the rejection that the existence of a real critical vision can generate within itself. However, the vertiginous technological change, the ubiquity of disinformation and the crucial role of the knowledge of the agents involved in it, and the development of critical thinking to face up to it forces the updating of this curriculum and its periodical review, making it more necessary than ever to approach it from a structural approach that favours a critical general public and the democratic process" [28].

Finally, and in line with what has been established so far, some authors suggest that the real solution to fight against fake news consists in applying a media education clearly, directly, and under clearly defined objectives [29]. 


\section{How to Stop Fake News in Times of COVID-19}

It is evident that, although media literacy is one of the main elements in the fight against fake news, it is also true that society as a whole has been decades late in applying it. Consequently, in the short term, it seems unlikely that this is the solution. However, a series of mechanisms have been put into place that help the user of social networks to filter this kind of information, as well as companies and entities with governmental support or entirely private companies, whose objective is to constantly analyse and report fake news.

Furthermore, some studies even propose the automatic detection of fake news as a response [30]. For example, in relation to this fact, in the case of Spain, there is the "Maldito Bulo" platform whose aim is to detect false information, but others, such as Truth-o-meter, also exist. Additionally, there is another series of tools that can improve the search quality of Internet information, such as a Google Chrome extension that launches an alert when you enter an unreliable or untrustworthy website or a satirical website (when it is not known if a website is humorous). In addition, it reports how much news from that medium has been disproved up to that moment [31].

As has been established, one of the main problems when dealing with control over fake news is found in social networks. In this regard, and as Brummette et al. [32] points out, their owners and founders must be involved to be part of the solution to the problem. Based on this, a series of proposals executed by the main social networks and by the main information search engines are presented below, taken from the works of Bustos Díaz and Ruiz del Olmo:

- Facebook, Twitter, and Instagram prominently place tools to fight against fake news, evidencing the concern on the part of social networks about the spread of false news, something that undermines the credibility of the channel.

- The involvement of the large social media platforms in this matter is due to two main issues: to reduce to a minimum the possible consumption of fake news by users, while at the same time seeking to consolidate the audience of the brand and to avoid losing users and credibility. That is, brands try to prevent themselves from becoming synonymous with fake news. Therefore, it can be concluded that it is a job that has two objectives: improving the user experience and maintaining the brand image.

- Secondly, the clear commitment of all of them to use official sources of recognised prestige as means of communication, whether press, digital, radio, or television [33].

- In all of them, the elimination of susceptible or possibly misleading accounts is a constant. As far as this is concerned, within the passive tools, we can see that the news centres created by Facebook and Twitter as well as the Instagram warning for users link directly to the World Health Organisation profile [33].

Together, the three case studies highlight the importance of quality journalism—of proven news in times of crisis. In this case, the three companies have used traditional media with proven trajectories and great credibility (despite the deterioration and general precariousness of journalistic information in recent years). There is no distinction by type of media, i.e., television, radio, and press, suggesting that the information from all of them is beyond the support that each one uses [34].

\section{Conclusions}

This work has theoretically addressed the conceptualisation of fake news, its evolution, its history, and the reasons that have allowed its rapid dissemination during the COVID-19 pandemic. Based on this, the following conclusions can be drawn.

In the first place, as has been shown in the development of this chapter of the book, the problem of fake news is not new. What we are experiencing now as a society is only an accentuated manifestation of a negative aspect of the information that has been manifesting itself in recent times. On the other hand, the need for the application in educational terms of media literacy is evident. The solutions addressed in the section "How to stop fake news in times of COVID-19" represent a temporary and short-term solution that does not fix the 
underlying problem, which is the lack of capacity of today's society to identify what is fake news and what is not.

It has also been shown that society today depends more than ever on quality journalism. Until the emergence of social networks, journalism represented a social political function that had been classified as "the fourth power". This lack of filtering of information, which has traditionally been known as the gatekeeper, is what search engines and social networks are applying. However, it seems more interesting that journalism once again assumes its role within the social context: "In a media ecosystem in which lies are institutionalised with over-information and a great abundance of sources, it is necessary to verify the veracity of the news, and here lies an opportunity for journalism" [20].

The role of politicians emerges as another key aspect in the fight against fake news. In this piece of work, a fact collected by scientific literature on this subject has been reflected. Donald Trump, for example, has become a viral phenomenon, contributing on many occasions false statements about the pandemic that have confused society. Finally, the academy is making a considerable effort to analyse, understand, and comprehend this phenomenon. Based on this, it has been observed that the term "fake news" was present in $50 \%$ of the keywords of the 10 most cited articles of the Web of Science and $70 \%$ of the most cited articles of Scopus [35]. Therefore, it seems clear that the problem must be addressed jointly, using media literacy as a driver and creator of a society more prepared to deal with fake news in combination with, as the political debate becomes more serious, a more rigorous press and an academy that continues to contribute new discoveries.

In short, we are witnessing a process in which the proliferation of fake news is flooding the digital ecosystem and, therefore, creating a social problem that can lead to collective hysteria and other associated processes. Although, as defined in this text, there are tools both in the main search engines and in social networks, we cannot leave the user aside. Digitalisation implies knowing how to use technologies, but, above all, using them responsibly. To this end, it is essential, as has been argued, to work on the process of media literacy and to go deeper in terms of social implantation in order to reduce the impact of fake news on society as a whole. Despite the existing filters in social networks and the main search engines, it is clear that fake news continues to penetrate society. Therefore, the need for media literacy has become an extremely relevant issue.

Author Contributions: Conceptualisation, J.B.D.; methodology, R.N.-S.; validation, R.N.-S.; formal analysis, R.N.-S.; investigation, R.N.-S. and J.B.D.; resources, J.B.D.; data curation, R.N.-S.; writingoriginal draft preparation, J.B.D.; writing-review and editing, R.N.-S.; project administration, J.B.D.; funding acquisition, J.B.D. All authors have read and agreed to the published version of the manuscript.

Funding: This research was funded by ESIC Business and Marketing, grant number ESIC 1-B-2021.

Institutional Review Board Statement: Not applicable.

Informed Consent Statement: Not applicable.

Conflicts of Interest: The authors declare no conflict of interest.

Entry Link on the Encyclopedia Platform: https:/ / encyclopedia.pub/16888.

\section{References}

1. The World Bank. Available online: https://data.worldbank.org/indicator/IT.NET.USER.ZS (accessed on 20 August 2021).

2. Statista. Available online: https://www.statista.com/ (accessed on 20 August 2021).

3. Castells, M. La Sociedad Red: Una Visión Global; Alianza Editorial: Madrid, Spain, 2006; ISBN 84-206-4784-5.

4. Newman, N.; Fletcher, R.; Schulz, A.; And1, S.; Kleis Nielsen, R. Reuters Institute Digital News Report 2020; Reuters Institute for the Study of Journalism: Oxford, UK, 2020; ISBN 978-1-907384-75-2.

5. Aguaded, J.I.; Romero-Rodríguez, L.M. Mediamorfosis y desinformación en la infoesfera: Alfabetización mediática, digital e informacional ante los cambios de hábitos de consumo informativo. Educ. Knowl. Soc. 2015, 16, 44-57. [CrossRef]

6. Rodríguez, C. "Fake news", palabra del año del Diccionario Oxford. In El Mundo; El Mundo: Madrid, Spain, 2017.

7. Gelfert, A. Fake News: A Definition. Informal Log. 2018, 38, 84-117. [CrossRef] 
8. Quandt, T.; Boberg, S.; Frischlich, L.; Schatto-Eckrodt, T. Fake News. In The International Encyclopedia of Journalism Studies; Wiley: New York, NY, USA, 2019; pp. 1-6. [CrossRef]

9. Lopez-Borrull, A.; Vives-Gràcia, J.; Badell, J.-I. Fake news, ¿amenaza u oportunidad para los profesionales de la información y la documentación? Prof. Inf. 2018, 27, 1346-1356. [CrossRef]

10. Oxford English Dictionary. Available online: https://www.oed.com/ (accessed on 20 August 2021).

11. Comisión Europea: Lucha Contra la Desinformación. Available online: https://ec.europa.eu/info/live-work-travel-eu/ coronavirus-response/fighting-disinformation_es\#trelatedlinks (accessed on 18 October 2021).

12. Capilla, P. ¿De qué hablamos cuando hablamos de posverdad? Análisis del término en siete diarios de calidad. Prof. Inf. 2019, 28, 1-13. [CrossRef]

13. Pérez-Dasilva, J.-A.; Meso-Ayerdi, K.; Mendiguren-Galdospín, T. Fake news y coronavirus: Detección de los principales actores y tendencias a través del análisis de las conversaciones en Twitter. Prof. Inf. 2020, 1-22. [CrossRef]

14. Salas Abad, C. La primera fake news de la historia. Hist. Comun. Soc. 2019, 24, 411-431. [CrossRef]

15. Lazer, D.M.; Baum, M.A.; Benkler, Y.; Berinsky, A.J.; Greenhill, K.M.; Menczer, F.; Metzger, M.J.; Nyhan, B.; Pennycook, G.; Rothschild, D.; et al. The science of fake news. Science 2018, 359, 1094-1096. [CrossRef]

16. Rodríguez-Fernández, L. Desinformación y comunicación organizacional: Estudio sobre el impacto de las fake news. Rev. Lat. Comun. Soc. 2019, 74, 1714-1728. [CrossRef]

17. Tandoc, E.C., Jr.; Ling, R.; Westlund, O.; Duffy, A.; Goh, D.; Zheng Wei, L. Audiences' acts of authentication in the age of fake news: A conceptual framework. New Media Soc. 2018, 20, 2745-2763. [CrossRef]

18. Parra Valero, P.; Oliveira, L. Fake news: Una revisión sistemática de la literatura. Observatorio OBS 2018, 12, 54-78. [CrossRef]

19. Alonso González, M. Fake News: Desinformación en la era de la sociedad de la información. Ámbitos Rev. Int. Comun. 2019, 45, 29-52. [CrossRef]

20. Romero y Olmo, J.A. Desinformación: Concepto y perspectivas. Análisis Real Inst. Elcano 2019, 41, 1-8.

21. Nelson, J.L.; Harsh, T. The small, disloyal fake news audience: The role of audience availability in fake news consumption. New Media Soc. 2018, 20, 3720-3737. [CrossRef]

22. Pangrazio, L. What's new about 'fake news'? Critical digital literacies in an era of fake news, post-truth and clickbait. Páginas Educ. 2018, 11, 6-22. [CrossRef]

23. Apuke, O.D.; Omar, B. Noticias falsas y COVID-19: Modelando los predictores del intercambio de noticias falsas entre los usuarios de las redes sociales. Telemát. Inf. 2021, 56, 101475. [CrossRef]

24. Casero-Ripollés, A. Impacto del COVID-19 en el sistema de medios. Consecuencias comunicativas y democráticas del consumo de noticias durante el brote. Prof. Inf. 2020, 1-12. [CrossRef]

25. Gutiérrez-Coba, L.M.; Coba-Gutiérrez, P.; Gómez-Díaz, J.A. Noticias falsas y desinformación sobre el COVID-19: Análisis comparativo de seis países iberoamericanos. Rev. Lat. Comun. Soc. 2020, 78, 237-264. [CrossRef]

26. Fernández-García, N. Fake news: Una oportunidad para la alfabetización mediática. Nueva Soc. 2017, 269, 66-77.

27. Gutiérrez, A.; Tyner, K. Educación para los medios, alfabetización mediática y competencia digital. Comunicar 2012, 19, 31-39. [CrossRef]

28. Alcolea-Díaz, G.; Reig, R.; Mancinas-Chávez, R. Currículo de Alfabetización Mediática e Informacional de la UNESCO para profesores desde la perspectiva de la Estructura de la Información. Comunicar 2020, 28, 103-114. [CrossRef]

29. Kendall, A.; McDougall, J. Alfabetización mediática crítica en la postmodernidad. Comunicar 2019, 19, 21-29. [CrossRef]

30. Pérez-Rosas, V.; Kleinberg, B.; Lefevre, A.; Mihalcea, R. Automatic detection of fake news. arXiv 2017, arXiv:1708.07104.

31. Magallón-Rosa, R. Nuevos formatos de verificación. El caso de Maldito Bulo en Twitter. Sphera Publ. $2018,1,41-62$.

32. Brummette, J.; DiStaso, M.; Vafeiadis, M.; Messner, M. Read all about it: The politicization of "fake news" on Twitter. J. Mass Commun. Q. 2018, 95, 497-517. [CrossRef]

33. Bustos-Díaz, J.; Ruiz-del-Olmo, F.J. Comunicar en tiempos de crisis en las redes sociales. Estrategias de verificación e intermediación informativa en los casos de Facebook, Instagram y Twitter durante la COVID-19. Hipertext Net 2020, $21,115-125$. [CrossRef]

34. Bustos-Díaz, J.; Ruiz-del-Olmo, F.J. Fuentes verificadas ante las Fakes News. El caso de Facebook, Google y Microsoft frente a la desinformación durante el COVID-19. Rev. Estilos Aprendiz. 2020, 13, 7-18.

35. Alfonso, I.B.; Galera, C.G.; Calvo, S.T. El impacto de las fake news en la investigación en Ciencias Sociales. Revisión bibliográfica sistematizada. Hist. Comun. Soc. 2019, 24, 449-469. [CrossRef] 